\title{
Quality traits reach market
}

\section{Andrew Marshall}

181.5 million hectares of biotech crops were grown globally in 2014. In the United States, the recent approval of a bruise-resistant Arctic apple followed that of a low-polyacrylamide, nonbrowning Innate potato (Nat. Biotechnol. 33, 12-13, 2015). Other quality traits in the field include

\section{Global area by transgenic trait}

Area of insect-resistant varieties shrank, but plantings of crops with stacked traits continued apace.

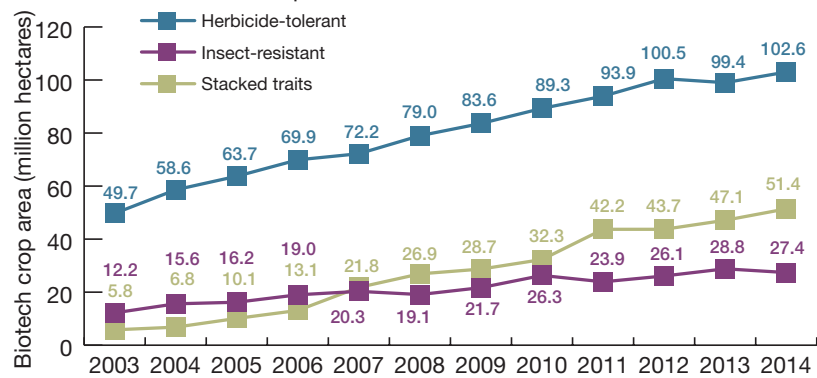

Source: International Service for the Acquisition of Agri-Biotech Applications.

\section{Global area of transgenic crops by country}

Canada caught up to India in terms of transgenic plantings; US, Brazil and Uruguay continued growth, but China, Australia, South Africa and Myanmar shrank in hectarage.

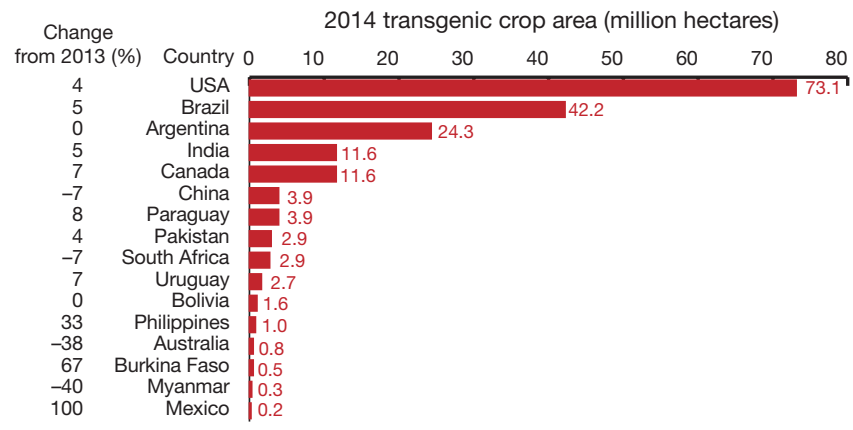

Source: International Service for the Acquisition of Agri-Biotech Applications.

\section{EU transgenic crop field trials}

Another low: Spain and Sweden dominate EU fields with four each of a total of 12 releases.

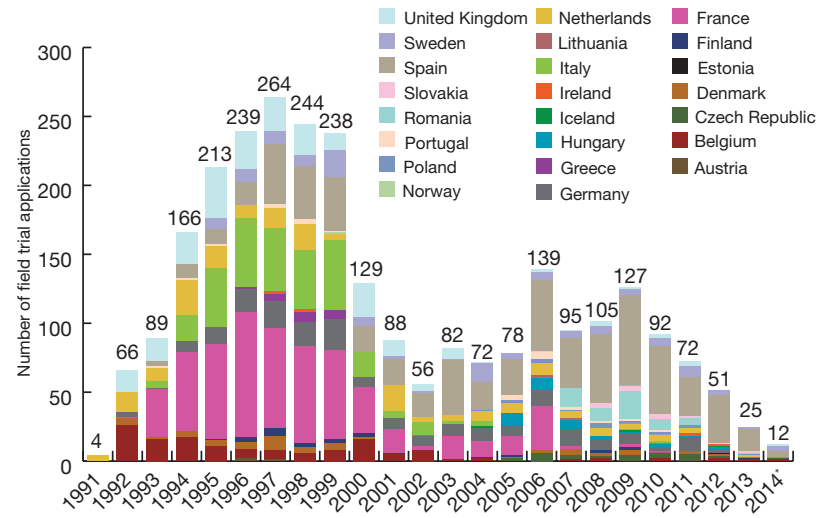

*2014 figures to be updated 4/26/15. Source: http://gmoinfo.jrc.ec.europa.eu/gmp_ browse.aspx

Andrew Marshall is Chief Editor at Nature Biotechnology. vitamin A-enriched rice, and bananas and maize with elevated omega-3 or oleic acid. Several maize varieties with improved nitrogen uptake are under testing; DroughtGard maize showed a 5.5-fold increase in US plantings. Bangladesh commercialized its first transgenic crop, Bt brinjal.

Historical global area and value of transgenic crops

Transgenic acreage grew $4 \%$ in 2014, representing 35\% of the global seed market.

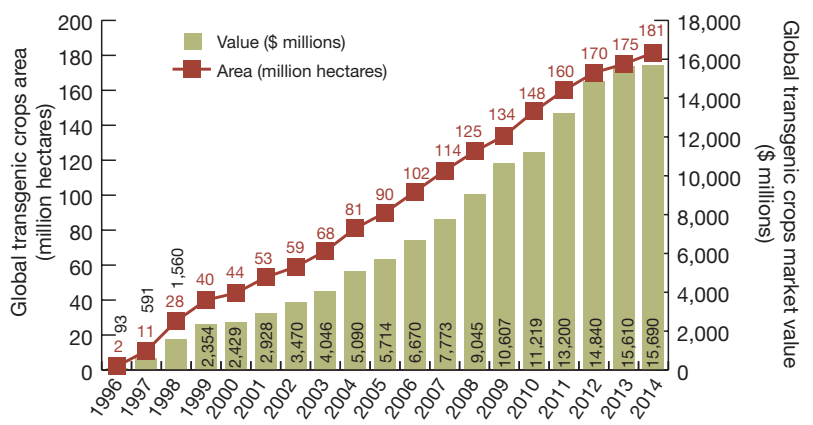

Source: International Service for the Acquisition of Agri-Biotech Applications. Value data are explicitly from seeds and licensing revenue rather than from 'crops' themselves.

\section{Transgenic crop adoption rate in the US}

All the major crops in the US are now predominantly transgenic.

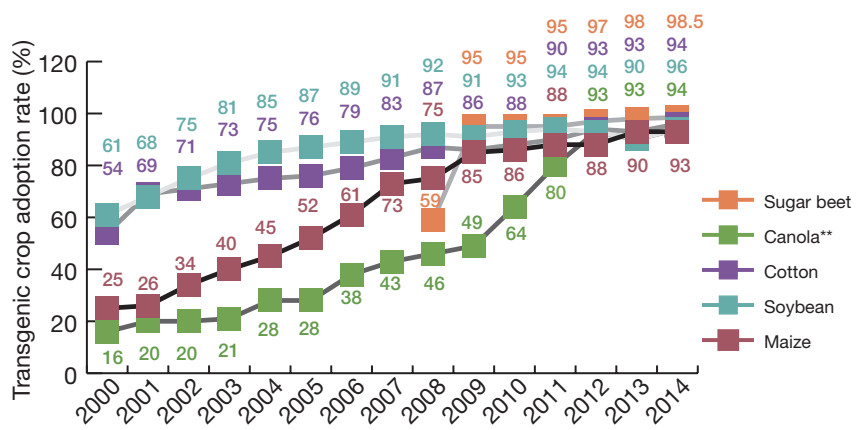

${ }^{* *}$ Canola adoption rates are based on global data rather than US data.

Source: International Service for the Acquisition of Agri-Biotech Applications; National Agricultural Statistics Service.

\section{Notable transgenic crop/traits receiving approval}

\begin{tabular}{|c|c|c|c|}
\hline Country & Crop & Company & Decision \\
\hline US & Alfalfa & Monsanto & $\begin{array}{l}\text { KK179 MON-00179-5 (HarvXtra) Transgenic alfalfa with } \\
\text { reduced lignin via expression of inverted repeats of caffeoyl } \\
\text { CoA 3-O-methyltransferase gene; resulting RNA interference } \\
\text { of endogenous gene reduces synthesis of the G lignin subunit. }\end{array}$ \\
\hline US & Soybean & $\begin{array}{l}\text { Dow } \\
\text { Agrosciences }\end{array}$ & $\begin{array}{l}\text { DAS-44406-6 (Enlist Duo) Transgenic soybean expressing } \\
\text { the aryloxyalkanoate dioxygenase } 12 \text { protein from Delftia } \\
\text { acidovorans under the control of AtUbi10 promoter, phos- } \\
\text { phinothricin acetyltransferase from Streptomyces viridochro- } \\
\text { mogenes under a cassava vein mosaic virus promoter, and } \\
\text { a mutated 5-enolpyruvylshikimate-3-phosphate synthase } \\
\text { gene from Zea mays under an XYZ promoter, which confer } \\
\text { resistance to 2,4-D choline, glufosinate ammonium and } \\
\text { glyphosate herbicides, respectively. }\end{array}$ \\
\hline US & Apple & Okanagan & $\begin{array}{l}\text { OKA-NBØØ1-8/OKA-NBØØ2-9 (Arctic) Transgenic Golden } \\
\text { Delicious or Granny Smith apples expressing a chimeric } \\
\text { polyphenol oxidase (PPO) suppression element derived from } \\
\text { apple PPO sequences under the control of the Cauliflower } \\
\text { mosaic virus promoter/5' untranslated leader sequence of } \\
\text { alfalfa mosaic virus RNA4, conferring reduced tissue brown- } \\
\text { ing in response to mechanical damage (e.g., slicing or bruis- } \\
\text { ing); a neomycin phosphotransferase kanamycin-selectable } \\
\text { marker is also present. }\end{array}$ \\
\hline
\end{tabular}

Source: http://bch.cbd.int/database/organisms/ 